\title{
Cash to Price Ratio \& Stock Returns: Evidence from Emerging Markets
}

\author{
Nudrat Fatima ${ }^{1}$, Muhammad Waqas ${ }^{1}$, Rameez Hassan ${ }^{2}$, Ahmad Fraz $^{3}$ \& Muhammad Arif ${ }^{4}$ \\ 1 Department of Management \& Social Science, Capital University of Science \& Technology, Islamabad, \\ Pakistan \\ ${ }^{2}$ Department of Economics, Aligarh Muslim University, AMU, India \\ 3 Department of Management \& Social Science, Capital University of Science \& Technology, Islamabad, \\ Pakistan \\ ${ }^{4}$ Department of Management Science, Govt. College of Management Sciences, Swabi, Pakistan \\ Correspondence: Muhammad Waqas, Department of Management \& Social Science, Capital University of \\ Science \& Technology, Islamabad Expressway, Kahuta Road, Zone-V, Islamabad, Pakistan.
}

Received: September 8, 2017

doi:10.5539/ijef.v9n11p153
Accepted: September 28, $2017 \quad$ Online Published: October 15, 2017

URL: https://doi.org/10.5539/ijef.v9n11p153

\begin{abstract}
This study examines the impact of size premium and value premium on average return in emerging economies i.e. Pakistan, India and China equity markets for the period from June 2000 to June 2015 by using three factors model. This study predicts the significance and positive relationship between value premium(C/P Ratio) and stock return for all non-financial companies listed on Karachi stock exchange, Bombay stock exchange and Shanghai stock exchange on the basis of market Capitalization. The regression results of the study illustrate that size premium predict returns more for small firms than big firms while market premium found significantly positive with stock returns in Pakistan, India, and China. Value premium is found positive for all created portfolios. Therefore, it can be concluded that value effect is present in three emerging markets. High $\mathrm{C} / \mathrm{P}$ ratio outperforms the low $\mathrm{C} / \mathrm{P}$ ratio stocks. In this study C/P ratio (value premium) integrated with size and market premium to check whether it can predict stock returns of small and large firms for high or low C/P ratio. The finding is similar that the positive relationship of value premium and stock return and the negative relationship of size premium and stock return. The explanatory power of Fama and French three-factor model is greater than CAPM for all three equity markets, so, the asset pricing model can facilitate investors in efficient portfolio diversification for getting enhanced returns.
\end{abstract}

Keywords: size \& value premium, stock return, emerging markets, CAPM

\section{Introduction}

Capital markets play a vital role in financial markets of any country. It is a fundamental factor to be considered while going for investment that how a market efficiently transforms information to stock prices. In recent studies, numbers of asset pricing models are discussed in academics. Capital asset pricing model (CAPM) of Sharp (1964), Lintner (1965) and Mossin (1966) is still a debatable topic in the modern finance literature. The CAPM makes a fundamental contribution to understanding the relationship between risk and return. Covariance between expected return of the market portfolio and stock return is related by CAPM. With time progression, many studies reported that single factor model cannot explain the return pattern. On the basis of previous results, Fama \& French $(1993,2014)$ introduced three factor and five-factor model. Cross-sectional average returns have been explained better than CAPM by using value and size premium. $(\mathrm{C} / \mathrm{P})$ the ratio is an indicator of the ability of the company to generate cash that it uses to run its business. It is better valuation than $\mathrm{P} / \mathrm{E}$ ratio. This ratio provides the better idea about the money available for the management of $\mathrm{R} \& \mathrm{D}$, marketing activities, dividend and shares repurchase etc. $(\mathrm{C} / \mathrm{P})$ ratio is a better measurement of stock's value than $\mathrm{P} / \mathrm{E}$ ratios. Investors prefer to use price to cash flow ratio because it adjusts for expenses i.e. depreciation and capital expenditures etc. $\mathrm{C} / \mathrm{P}$ ratio is one of the most important financial indicators in evaluating a stock return. Fama and French (1992) have found that future stock return is predicted by the value premium. The origin of asset pricing theory is provided by CAPM presented by Sharp (1964) and Lintner (1972). The return on stock and risk relationship is expressed by CAPM. Only single-factor market premium $\left(\mathrm{Rm}-\mathrm{R}_{\mathrm{f}}\right)$ is affected by portfolio returns according to CAPM. Roll (1977) 
presents the arbitrage pricing theory (APT) as an alternate model that identifies the problems in CAPM. The arbitrage pricing theory (APT) is an alternative model for CAPM as APT is more generalized than CAPM. To determine the asset prices APT is used. CAPM depends on market portfolios whereas, APT does not depend on market portfolios, that explain expected returns are influenced by market risk. The APT assumes a return on equity as well as the efficiency of the portfolio and it depends on a number of factors. APT has three assumptions. First, more wealth is preferred than less wealth by investors. Secondly, generating returns process is a linear function of different factors. Thirdly, there is a perfectly competitive capital market. Expected risk and return relationship are explained by APT by using different assumptions. Fama and French (1992) examined the three-factor model. Three-factor model is a multi-factor model of APT. They studied the combined role of P/E ratio, beta, $\mathrm{B} / \mathrm{M}$ and size for cross-sectional variation in expected returns of stocks of NYSE, AMEX, and NASDAQ. And found that size and B/M ratio and market beta explain cross-sectional changes in expected stock returns. To explain the variation in returns, these two variables also absorb the effect of leverage and P/E. Various studies have been conducted on value premium and size premium. But there is less evidence available on value premium by using the cash to price proxy. Moreover, certain studies have been conducted in developed countries in which C/P ratio is used as a proxy for value premium. Cash flow analysis is certainly some portion of financial analysis in which managers, administration, administrators, investors, and stakeholders can use to decide the effectiveness of an organization's overall strategies. Evidence from emerging markets is limited. Therefore, there is a need of time to investigate these phenomena. $\mathrm{C} / \mathrm{p}$ ratio is another technique to $\mathrm{P} / \mathrm{E}$ ratio. This ratio removes the effect of non-cash items and gives reasonable and strong results with no conscious or deliberate control. This offers investors some assistance with judging the actual position of an organization and then deciding how investors should position their portfolios. This study aim with the following objectives. To check the impact of size on equity returns of emerging markets. To provide insight into the role of Cash to price ratio explaining the equity market return. To compare the Cash to price ratio dynamics of Asian emerging markets. The emerging markets (Pakistan, India, and China) are a good source of investment and portfolio diversification because of investors' interest. To get high returns on investment and highly growing markets with good quality of financial reporting these emerging markets are very important. This study is an effort to capture the current dynamics of the equity market and fill the gap in existing literature by extending the work in cash flow yield domain. This study is an effort to explain the effect of $\mathrm{C} / \mathrm{P}$ ratio on stock returns in three emerging markets i.e. Pakistan, India, and China. The significance of the study is to test the model taking proxies for future changes of expected returns, which can be useful for future practical execution by an extensive variety of interested investors making an investment decision. The predictability of stock returns has a financial significance for investors while formulating investment policy and allotting resources to portfolios. The study can contribute to better understanding of predicting the power of C/P ratio, Firm size in explaining the stock return variation. It is fascinating to see and give empirical support of the research in Cross-comparison of results of three countries (Pakistan, China, and India) that can motivate further innovative research in this field.

\section{Literature Review}

Portfolio theory is introduced by Harry Markowitz in 1950. Increasing returns for given level of risk and for given level of return taking lower risk is explained by modern theory. This work gave the edge to develop the Capital Asset Pricing theory such as (Treynor, 1962; Sharp, 1964; Lintner, 1972). Because of their applicability and simplicity in various situations these asset pricing theories, APT \& CAPM endure prevalently. (Mossin, 1996) studied the development of investor's utility function by making investigation through equilibrium model of such portfolios that have risky assets and identified the presence of market line and predicted risk in pricing mechanism. (Pastor \& Stambaugh, 2000) examined the investor's preferences of portfolios that choose portfolios on some asset-pricing models. (Black, Jensen, \& Scholes 1972) examined the stock returns and volatility relationship in US market. They used the cross-sectional monthly data from 1931 to 1965 time period. Findings of the study revealed that there is a positive and significant relationship between returns and beta, therefore, CAPM is applicable in US market. The anomaly is introduced by (Kuhn, 1970). Market inefficiency has the evidence of anomalies. According to Schwert (2001), "anomalies are empirical results that seem to be inconsistent with maintained theories of asset pricing". Investors can get the opportunities to increase the return on investment by using anomalies. Size effect explains firms have high market capitalization earn low returns than those firms that have low market capitalization. SMB determines that small size firms have the power to outperform the large size firms. The size effect in the cross-section of stock returns is one of the most established and best-known asset pricing anomalies. Since (Banz, 1981) reported that small firms earn higher returns than large firms, a large body of research has evolved on the size effect. (Basu, 1977) showed that the Price earning $\mathrm{E} / \mathrm{P}$ ratio and risk-adjusted returns are related to each other. The ratio of earnings to-price E/P is a wide proxy for unknown risk variables in expected returns, (Ball, 1978). The contradiction of the CAPM is directly affected by 
E/P ratio. The study of (Reinganum, 1981) confirmed and extended the findings of (Basu. Rosenberg, Reid, \& Lanstein, 1985) that gave confirmation against the CAPM by demonstrating that book-to-market ratio is significantly co-related with average returns. Furthermore, a strong positive BTM effect was founded by (Fama \& French, 1992) that suggest firms having higher BTM ratios have higher expected average returns. The study used the D/E ratio as an additional variable to explain the expected stock return. The study of (Bhandari, 1988) examined that the expected returns on common stock and debt to equity ratio are positively related with each other when other variables i.e. beta and size are used as control variables. The coefficient of D/E ratio is $0.13 \%$ per month by excluding January effect and $0.09 \%$ by including January effect and he finds that $\mathrm{D} / \mathrm{E}$ ratio is a just proxy for risk. The study of cash flow yield gained importance after the study of (Beaver, 1996). (Fama \& French, 1992) showed that stocks with high P/E ratio procure higher returns. (Chan, Hamao, \& Lakonishok, 1991) show that a high ratio of $\mathrm{C} / \mathrm{P}$ ratio also predicts higher returns. The book to market ratio and cash flow positively affects expected returns (Chan, Hamao, \& Lakonishok, 1991). Drew and Veeraraghaveen (2003) examine the descriptive power of FF three models for some markets such as Hong Kong, Malaysia, Korea and Philippines market. They found the presence of value premium and size premium in these market.They also found the CAPM has low explanatory power than FF three-factor model for variations in Stock Returns. Gomes et al. (2003) study the relationship b/w size and book to market with variation in stock returns. Growth options are equal for all firms. Firms with high growth have a low investment because they pay dividends. Value firms have high cash flow duration than growth firms and it has more positive stock returns.

Djajadikerta and Nartea (2005) investigate the behavior of size premium and value premium for return and also check the ability of Fama and French three-factor model to make clearance of the variations of stock returns. After the analysis results suggest a significant relationship between size and stock return but the weak relation with book-to-market. This study also reveals that CAPM is not better clarifications of expected returns in New Zealand stock market as compared to Fama and French three-factor model. Rutledge, Zhang, and Karim (2008) examined the relationship between stock returns and firm size in Chinese Market. Their findings reveal that smaller firms are more reactive than large firms towards the market. Large firms have low returns than small firm's value effect was not examined. The study of Hassan and Javed (2011) also examined the effect of size premium and value premium present in the stock market of Pakistan. Value premium is significantly positive for all portfolios except low $\mathrm{B} / \mathrm{M}$ stock. The results also demonstrate that $\mathrm{B} / \mathrm{M}$ effect is present in Pakistani equity market. Stocks having high B/M outperform the stocks having low B/M. size premium is significant and positive for small portfolio returns and for big portfolios return it is insignificant.

Empirical evidence on the different stock market show that Fama \& French Model has higher explanatory power than CAPM. However different results can be found as a selection of portfolio play important role in this (Blanco, 2012).

Choi (2013) used time-varying beta method. This study examined some more evidence for the explanation of value premium on the basis of risk. Security risk and financial leverage of value stock increase during an economic recession. However, this model failed to explain $60 \%$ of the value premium. In (2014), Fama and French have released a working paper in which they added two more factors that is profitability and investment along with three factors model and claimed that cross-sectional variations in expected returns can be better explained by their five factors model. After publishing grounds of three-factor model, Fama and French conducted more studies. They have explained that there are more factors that have effect on expected stock return. These factors include size, value, profitability and investment pattern. They have found companies with higher earnings will have higher stock market returns. They explained that five-factor model has explanatory power for cross-section variation of expected return is in between $71 \%$ to $94 \%$ (Fama \& French, 2015)

\section{Data and Methodology}

\subsection{Data Description}

This study includes the monthly closing prices of 180 companies, sixty listed companies having a large market capitalization of each stock market including Pakistan Stock Exchange (PSE) for Pakistan, Bombay Stock exchange (BSE) for India and Taiwan Economic Journal Database(TEJ) for China for the time period of 2000 to 2015. Market index return of each of the market is used as the return of the market portfolio and 6 month T-bill rates are used as a proxy for the risk-free rate.

\subsection{Methodology}

As indicated by Capital Asset Pricing Model developed by Sharp just market premium is one factor that influences the returns, however, Arbitrage Pricing Theory says different variable impact the return, for C/P ratio, B/M ratio, and size etc. After the APT, Fama and French $(1992,1993)$ introduced three models in which value 
premium and size premium with a market premium has been used. FF three-factor methodologies have been adopted to examine the effect of $\mathrm{C} / \mathrm{P}$ ratio on stock returns.

Portfolios are constructed as:

\subsection{Portfolio Construction}

* At the starting level, the general portfolio is created and after that general portfolio sorted on the premise of the size.

* The market capitalization of 60 companies is established for size sorted portfolio. On the basis of business sector capitalization companies are masterminded at this point. $\mathrm{S}$ is the group of small 30 companies and $\mathrm{B}$ be the group of biggest 30 companies.

* Size sorted portfolio B are further sorted on the premise of high and low C/P ratio to make C/P sorted variable. 15 companies with high-low $\mathrm{C} / \mathrm{P}$ ratio have been named as $\mathrm{B} / \mathrm{H}$ and 15 companies with low $\mathrm{C} / \mathrm{P}$ ratio have been named as $\mathrm{B} / \mathrm{L}$.

* Similarly, the example of 30small (S) low C/P ratio has additionally classified to make C/P sorted values on the basis of high $\mathrm{C} / \mathrm{P}$ and low $\mathrm{C} / \mathrm{P}$ ratios. There are 15 companies having high $\mathrm{C} / \mathrm{P}$ ratio categorized as $\mathrm{S} / \mathrm{H}$ also 15 organizations having low $\mathrm{C} / \mathrm{P}$ are categorized as $\mathrm{S} / \mathrm{L}$.

* The average return for all of the companies' portfolios has been calculated.

* From 2000 to 2015 the portfolios have been constructed by repeating the above-expressed methods.

\subsection{Variable Construction}

So as to construct the variable size, market capitalization is used as a proxy for size. Market Capitalization $=$ MPS x No. of extraordinary shares

Size premium is calculated by following expressions after computing the measure of companies.

$$
\text { Size Premium }=S M B=1 / 2[(S / H-B / H)+(S / L-B / L)
$$

The variable Value premium(C/P Ratio) is developed in the following manner. It is calculated by using the formula as:

\section{CASHPERSHARE $=$ Cash $/$ No. of Shares}

$\mathrm{C} / \mathrm{P}$ Ratio $=$ Cash Per share $/ \mathrm{MPS}$

Value premium(C/P Ratio) is calculated by the following expression.

$$
H M L=1 / 2[(S / H-S / L)+(B / H-B / L)
$$

HML refer to the difference between the high C/P Ratio and low C/P Ratio of the firms.

The following formula is used for the market premium.

Market premium $=$ MKT $=(\mathrm{Rmt}-\mathrm{Rft})$

Where, $\mathrm{Rmt}=\mathrm{Ln}(\mathrm{lt} / \mathrm{lt}-1)$

$\mathrm{Rmt}$ is the market return for " $\mathrm{t}$ " month and lt and lt-1 represent the closing prices of the index for "t" months and "t-1" respectively. $\mathrm{Rft}$ is the T-bill rate.

\subsection{Model Specification}

This study is using multivariate regression, two pas regression model, and Fama and French $(1992,1993)$ methodology. The equation would be:

$$
\begin{gathered}
R_{p t}-R f t_{=} \alpha+\beta_{I}(\text { Market premium })+\beta 2 \text { (Size premium) }+\beta 3 \text { (Value premium) }+e_{t} \\
R_{p t}-R_{f t=} \alpha+\beta_{I}\left(R_{m}-R_{f}\right)+\beta 2 S M B t+\beta 3 H M L t+e_{t} \\
R_{p t}-R_{f t} f t=y+y 1 \beta t(M K T)+y 2 \beta t(S M B)+y 3 \beta t(H M L)+
\end{gathered}
$$

This equation will cover the accompanying measurements:

$\mathrm{R}_{\mathrm{ft}}=$ Risk-free Rate

$\mathrm{R}_{\mathrm{m}}-\mathrm{R}_{\mathrm{FR}}=$ Market premium

$\mathrm{SMB}=$ Size premium $=$ Small - Big

$\mathrm{HML}=$ the value premium $=\mathrm{High} \mathrm{C} / \mathrm{P}$ ratio- Low $\mathrm{C} / \mathrm{P}$ ratio 
$\alpha=$ the management impact (Alpha) $\mathrm{e}_{\mathrm{t}}=$ error term

$y=$ Coefficient

$\beta_{\mathrm{t}(\mathrm{MKT})=}$ Beta of market premium $\beta_{\mathrm{t}}$ (SMB)= Beta of the size premium

$\beta_{t(\mathrm{HML})=}$ Beta of the value premium

\section{Results and Discussion}

Table 1 shows the behavior of the data. Mean, shows the central tendency of the data whereas standard deviation explains the dispersion of the data that how much data is deviated from its mean. Minimum and maximum values represent the scattering of the data. The results indicate that average returns earned by portfolios range from 0.002 to 0.007 . The maximum average profit is reported by portfolio $B / H$ and $B / L$ and the minimum average profit is reported by portfolio $\mathrm{S} / \mathrm{L}$. During the sample period, the maximum loss reported by portfolio $P$ and $S / H$ is (-.097), (-.096) respectively. The maximum profit also earned by portfolio $P$ and portfolio $S / H$ is (0.100), (0.100). The maximum standard deviation is reported by portfolio $P, S / H$ and $B / L$ that is 0.040 . Statistical properties of portfolios reported in the table for India, indicate that average returns earned by the portfolios range from 0.003 to 0.024 . Maximum return reported by portfolio $B / H$ and $S / L$ is 0.237 and 0.181 and the minimum return earned by portfolio $S$. Maximum average loss is -0.212 reported by portfolio $S / L$. The standard deviation of the portfolios ranges from 0.034 to 0.056 maximum standard deviation is 0.056 reported by $B / H$. Results of descriptive statistics regarding China depicts that portfolio $P$ has the mean value 0.005 with standard deviation 0.008 , the maximum value is 0.018 and minimum value -0.020 . $S$ portfolio has the mean value 0.022 with standard deviation 0.063 , minimum value -0.176 and maximum value 0.255 . Whereas portfolio $B$ has mean value 0.004 with standard deviation 0.063 , minimum value -0.084 and maximum value 0.109 . $S$ is high risk and high return portfolio as compared to $B$ which is low risk and low return portfolios. $S / H$ is high return and high-risk portfolio as compared with $S / L$ which low risk and low return portfolio. The average return earns by portfolio $S / H$ is 0.011 with standard deviation 0.054 . Minimum average return reported is -0.149 and maximum return is 0.170 . While average return reported by portfolio $\mathrm{S} / \mathrm{L}$ is 0.007 with a standard deviation of 0.051 , the minimum return is -0.212 and maximum return is 0.137 .

Table 1. Descriptive statistics

\begin{tabular}{lccccccc}
\hline Variable & P & S & B & S-H & S-L & B-H & B-L \\
\hline Panel A-Descriptive Statistics for Pakistan & & & & & & 0.007 \\
\hline Mean & 0.004 & 0.006 & 0.008 & 0.003 & 0.002 & 0.007 & 0.007 \\
Median & 0.007 & 0.007 & 0.008 & 0.007 & 0.007 & 0.009 & 0.040 \\
SD & 0.040 & 0.037 & 0.034 & 0.040 & 0.037 & 0.032 & 0.105 \\
Kurtosis & 0.443 & 0.600 & 0.006 & 0.315 & 0.311 & -0.152 & 0.074 \\
Skewness & -0.066 & -0.097 & 0.195 & -0.146 & -0.258 & 0.032 & -0.073 \\
Min & -0.097 & -0.073 & -0.056 & -0.096 & -0.077 & -0.057 & 0.087 \\
Max & 0.100 & 0.084 & 0.079 & 0.100 & 0.076 & 0.069 & \\
\hline Panel B-Descriptive Statistics for India & & & & & & 0.012 \\
\hline Mean & 0.003 & 0.014 & 0.024 & 0.006 & 0.009 & 0.009 & 0.010 \\
Median & 0.004 & 0.008 & 0.015 & 0.008 & 0.014 & 0.002 & 0.055 \\
SD & 0.041 & 0.034 & 0.042 & 0.041 & 0.042 & 0.056 & 1.254 \\
Kurtosis & 0.050 & 0.079 & 0.306 & 0.520 & 2.666 & 1.912 & -0.146 \\
Skewness & 0.349 & -0.141 & 0.156 & 0.094 & -0.726 & 0.145 & -0.177 \\
Min & -0.090 & -0.071 & -0.109 & -0.096 & -0.212 & -0.177 & 0.170 \\
Max & 0.090 & 0.085 & 0.109 & 0.120 & 0.181 & 0.237 & \\
\hline Panel C-Descriptive Statistics for China & & & & & & 0.011 \\
\hline Mean & 0.005 & 0.022 & 0.004 & 0.011 & 0.007 & 0.009 & 0.013 \\
Median & 0.005 & 0.022 & 0.003 & 0.010 & 0.012 & 0.012 & 0.056 \\
SD & 0.008 & 0.063 & 0.024 & 0.054 & 0.051 & 0.055 & 1.040 \\
Kurtosis & 1.010 & 2.230 & 5.656 & 0.650 & 2.558 & 1.091 & -0.130 \\
Skewness & -0.924 & 0.039 & 0.771 & 0.008 & -1.026 & -0.195 & -0.177 \\
Min & -0.020 & -0.176 & -0.084 & -0.149 & -0.212 & 0.170 \\
Max & 0.018 & 0.255 & 0.109 & 0.170 & 0.137 & 0.170 & 0.170 \\
\hline S & & & & & & \\
\hline
\end{tabular}

Note. $\mathrm{S}$ and $\mathrm{B}$ denote small and big and $\mathrm{S} / \mathrm{L}, \mathrm{S} / \mathrm{H}, \mathrm{B} / \mathrm{L}, \mathrm{B} / \mathrm{H}$, small low cash to price, small high cash to price, big low cash to price and big high cash to price. 
Table 2. Fama and French three factors model

\begin{tabular}{|c|c|c|c|c|c|c|c|c|c|c|c|c|c|c|}
\hline Variable & $\mathbf{P}$ & $\mathbf{P}$ & $\mathbf{S}$ & $\mathbf{S}$ & B & B & $\mathrm{S} / \mathrm{L}$ & S/L & S/H & S/H & $\mathrm{B} / \mathrm{L}$ & $B / L$ & B/H & B/H \\
\hline \multicolumn{15}{|c|}{ Panel A- Regression for Pakistan } \\
\hline$\alpha$ & 0.007 & 0.004 & 0.007 & 0.005 & 0.011 & 0.005 & 0.015 & 0.006 & 0.015 & 0.004 & 0.009 & 0.003 & 0.004 & 0.002 \\
\hline T Value & 2.162 & 1.898 & 2.325 & 1.786 & 3.098 & 2.128 & 3.693 & 1.766 & 3.693 & 1.261 & 2.142 & 0.816 & 1.166 & 0.723 \\
\hline$P$ value & 0.032 & 0.059 & 0.021 & 0.076 & 0.002 & 0.035 & 0.000 & 0.079 & 0.000 & 0.209 & 0.034 & 0.415 & 0.245 & 0.471 \\
\hline$\beta 1$ & 0.865 & 0.728 & 0.833 & 0.707 & 0.629 & 0.495 & 0.723 & 0.647 & 0.723 & 0.513 & 0.526 & 0.419 & 0.781 & 0.672 \\
\hline T Value & 11.854 & 13.118 & 12.140 & 11.801 & 7.655 & 9.265 & 7.453 & 7.675 & 7.453 & 7.654 & 5.671 & 5.478 & 8.819 & 8.445 \\
\hline$P$ value & 0.000 & 0.000 & 0.000 & 0.000 & 0.000 & 0.000 & 0.000 & 0.000 & 0.000 & 0.000 & 0.000 & 0.000 & 0.000 & 0.000 \\
\hline $\boldsymbol{\beta 2}$ & & 0.882 & & 0.752 & & 0.981 & & 0.872 & & 0.794 & & 0.827 & & 0.854 \\
\hline T Value & & 13.355 & & 9.571 & & 14.646 & & 8.933 & & 10.138 & & 8.743 & & 10.073 \\
\hline$P$ value & & 0.000 & & 0.000 & & 0.000 & & 0.000 & & 0.000 & & 0.000 & & 0.000 \\
\hline$\beta 3$ & & 0.120 & & 0.070 & & 0.482 & & 0.177 & & 0.279 & & 0.334 & & 0.219 \\
\hline T Value & & 1.579 & & 0.780 & & 6.288 & & 1.461 & & 3.267 & & 3.116 & & 2.074 \\
\hline$P$ value & & 0.116 & & 0.000 & & 0.000 & & 0.146 & & 0.001 & & 0.002 & & 0.040 \\
\hline Adj.R^2 & 0.438 & 0.720 & 0.450 & 0.637 & 0.243 & 0.711 & 0.234 & 0.472 & 0.234 & 0.541 & 0.148 & 0.442 & 0.300 & 0.560 \\
\hline F-Stat & 140.508 & 154.050 & 147.374 & 105.539 & 58.606 & 148.059 & 55.552 & 54.429 & 55.552 & 71.409 & 32.162 & 48.343 & 77.771 & 76.947 \\
\hline F Sig. & 0.000 & 0.000 & 0.000 & 0.000 & 0.000 & 0.000 & 0.000 & 0.000 & 0.000 & 0.000 & 0.000 & 0.000 & 0.000 & 0.000 \\
\hline \multicolumn{15}{|c|}{ Panel B-Regression for India } \\
\hline$\alpha$ & 0.005 & 0.003 & 0.016 & 0.013 & 0.009 & 0.003 & 0.002 & 0.000 & 0.004 & 0.004 & 0.005 & 0.003 & 0.007 & 0.005 \\
\hline T Value & 1.693 & 1.251 & 3.975 & 3.752 & 2.491 & 1.198 & 0.659 & 0.080 & 1.649 & 1.510 & 1.666 & 1.259 & 2.316 & 1.944 \\
\hline P value & 0.092 & 0.212 & 0.000 & 0.000 & 0.014 & 0.233 & 0.511 & 0.936 & 0.101 & 0.133 & 0.097 & 0.210 & 0.022 & 0.054 \\
\hline $\boldsymbol{\beta 1}$ & 0.732 & 0.638 & 0.822 & 0.647 & 0.765 & 0.634 & 0.669 & 0.549 & 0.947 & 0.919 & 0.827 & 0.699 & 0.909 & 0.755 \\
\hline T Value & 10.635 & 9.975 & 8.837 & 7.515 & 9.216 & 11.060 & 7.410 & 6.851 & 15.930 & 15.828 & 10.454 & 11.059 & 12.066 & 12.291 \\
\hline$P$ value & 0.000 & 0.000 & 0.000 & 0.000 & 0.000 & 0.000 & 0.000 & 0.000 & 0.000 & 0.000 & 0.000 & 0.000 & 0.000 & 0.000 \\
\hline$\beta 2$ & & 0.560 & & 0.660 & & 0.949 & & 0.884 & & 0.347 & & 0.911 & & 0.828 \\
\hline T-Value & & 7.137 & & 6.250 & & 13.205 & & 10.357 & & 4.806 & & 12.113 & & 11.324 \\
\hline$P$ value & & 0.000 & & 0.000 & & 0.000 & & 0.000 & & 0.000 & & 0.000 & & 0.000 \\
\hline$\beta 3$ & & 0.179 & & 0.502 & & 0.469 & & 0.247 & & -0.119 & & 0.070 & & 0.217 \\
\hline T Value & & 1.991 & & 4.141 & & 5.705 & & 2.326 & & -1.494 & & 0.815 & & 2.577 \\
\hline P value & & 0.048 & & 0.000 & & 0.000 & & 0.021 & & 0.137 & & 0.416 & & 0.011 \\
\hline Adj.R^2 & 0.385 & 0.527 & 0.301 & 0.465 & 0.319 & 0.706 & 0.231 & 0.529 & 0.585 & 0.633 & 0.377 & 0.657 & 0.447 & 0.683 \\
\hline F-Stat & 113.106 & 67.348 & 78.094 & 52.922 & 84.927 & 144.562 & 54.905 & 67.926 & 53.749 & 3.940 & 109.293 & 15.266 & 45.587 & 29.523 \\
\hline F Sig. & 0.000 & 0.000 & 0.000 & 0.000 & 0.000 & 0.000 & 0.000 & 0.000 & 0.000 & 0.000 & 0.000 & 0.000 & 0.000 & 0.000 \\
\hline \multicolumn{15}{|c|}{ Panel C- Regression for China } \\
\hline$\alpha$ & 0.008 & 0.006 & 0.010 & 0.008 & 0.008 & 0.003 & 0.009 & 0.007 & 0.011 & 0.008 & 0.005 & 0.005 & 0.009 & 0.006 \\
\hline T Value & 3.090 & 2.779 & 3.322 & 3.079 & 2.044 & 0.821 & 3.021 & 2.824 & 3.583 & 3.285 & 1.446 & 1.676 & 2.914 & 2.458 \\
\hline P value & 0.002 & 0.006 & 0.001 & 0.002 & 0.042 & 0.413 & 0.003 & 0.005 & 0.000 & 0.001 & 0.150 & 0.096 & 0.004 & 0.015 \\
\hline$\beta 1$ & 0.992 & 0.902 & 0.872 & 0.771 & 0.861 & 0.789 & 0.731 & 0.637 & 0.792 & 0.650 & 0.779 & 0.800 & 0.741 & 0.599 \\
\hline T Value & 17.096 & 18.931 & 12.733 & 13.543 & 9.749 & 9.735 & 10.852 & 11.688 & 11.512 & 12.196 & 10.463 & 11.421 & 10.478 & 11.248 \\
\hline$P$ value & 0.000 & 0.000 & 0.000 & 0.000 & 0.000 & 0.000 & 0.000 & 0.000 & 0.000 & 0.000 & 0.000 & 0.000 & 0.000 & 0.000 \\
\hline$\beta 2$ & & 0.663 & & 0.769 & & 0.856 & & 0.794 & & 0.724 & & 0.465 & & 0.883 \\
\hline T-Value & & 10.485 & & 10.183 & & 7.338 & & 10.963 & & 10.668 & & 5.007 & & 12.486 \\
\hline$P$ value & & 0.000 & & 0.000 & & 0.000 & & 0.000 & & 0.000 & & 0.000 & & 0.000 \\
\hline$\beta 3$ & & 0.078 & & 0.072 & & -0.004 & & 0.014 & & 0.411 & & -0.451 & & 0.244 \\
\hline T Value & & 1.102 & & 0.856 & & -0.034 & & 0.178 & & 5.168 & & -4.332 & & 3.079 \\
\hline Pvalue & & 0.272 & & 0.393 & & 0.973 & & 0.859 & & 0.000 & & 0.000 & & 0.002 \\
\hline Adj. $R^{\wedge} 2$ & 0.619 & 0.764 & 0.474 & 0.666 & 0.344 & 0.494 & 0.395 & 0.636 & 0.424 & 0.680 & 0.377 & 0.495 & 0.378 & 0.676 \\
\hline F-Stat & 292.279 & 194.405 & 162.127 & 120.046 & 95.044 & 59.212 & 17.771 & 105.431 & 32.517 & 28.046 & 109.476 & 59.474 & 9.795 & 25.697 \\
\hline F Sig. & 0.000 & 0.000 & 0.000 & 0.000 & 0.000 & 0.000 & 0.000 & 0.000 & 0.000 & 0.000 & 0.000 & 0.000 & 0.000 & 0.000 \\
\hline
\end{tabular}

Table 2 reports single factor model CAPM and Fama and French three factor model analysis by regressing different type of portfolios (stock returns). The explanatory power of CAPM and three-factor model has been explored through simple regression analysis to capture the relationship among market, size and value premium in Pakistan, India \& China. CAPM results for the overall portfolio P indicates that there is the significant and positive effect of market premium with $t$ value 11.854 that shows CAPM fundamentally explain variation in stock return. The adjusted $\mathrm{R}^{2}$ is 0.438 that means market premium explain $43.8 \%$ variation in portfolio $\mathrm{P}$. This shows market premium and stock returns has a direct relationship that can be predictable with CAPM. Fama \& French three factors model results indicate $M K T$ and $C / P$ ratio is significant and positive while size is insignificant that shows $M K T$ and $C / P$ ratio explains variation in stock returns. An adjusted $R^{2}$ increased from 
0.438 to 0.720 that shows an increase in explanatory power of model in predicting the stock returns due to market, size and value premium. The table results show the contribution of $S M B$ and $H M L$ in the presence of $M K T$ in predicting the average returns of portfolios. $P$ values at $95 \%$ confidence level are significant indicates that proposed model has a significant impact on stock returns in Pakistan equity market. For India $P$ portfolio comprises of all stocks is regressed with $M K T$, it is found significant and positive with T-value 10.635, that shows $M K T$ fundamentally explain variation in stock return. An adjusted $\mathrm{R}^{2}$ is 0.385 that means market premium explain 38.5\% variation in overall portfolio stock returns. It also reports the CAPM and Fama and French three factor model analysis by regressing different type of portfolios (stock returns) of China stock market. CAPM results of $P$ portfolio indicate that $M K T$ is significant and positive with T- value17.096 that shows $M K T$ fundamentally explain variation in stock return. An adjusted $\mathrm{R}^{2}$ is 0.619 that means market premium explain $61.9 \%$ variation in overall portfolio stock returns. It shows that market premium has a significant relationship with stock returns which is consistent with CAPM. Fama and French three factor model results indicate $M K T$ and $C / P$ are significant and positive however the size is insignificant that shows $M K T$ and $C / P$ explains variations in stock returns.

The results indicate that single factor model CAPM explain variation in stock returns and is a valid model for all stocks. But Fama and French three factor model have the more explanatory power of model in predicting stock returns due to size and value premium than CAPM. The above table results show the contribution of $S M B$ and $H M L$ in the presence of MKT in predicting the average returns of portfolios. $P$ values at $95 \%$ confidence level are significant indicates that proposed model has a significant impact on stock returns in Pakistani, Indian \& Chinese stock market.

Table 3. Descriptive statistics for FF-3FM

\begin{tabular}{lccccccccc}
\hline & \multicolumn{3}{c}{ Pakistan } & \multicolumn{3}{c}{ India } & \multicolumn{3}{c}{ China } \\
\hline Mean & MKT & SMB & HML & MKT & SMB & HML & MKT & SMB & HML \\
Median & 0.003 & -0.005 & 0.001 & 0.009 & -0.003 & 0.003 & 0.004 & -0.003 & 0.017 \\
SD & 0.080 & -0.002 & 0.001 & 0.009 & -0.001 & 0.003 & 0.010 & 0.002 & 0.020 \\
Kurtosis & 1.506 & -0.457 & 1.396 & 1.823 & 1.874 & 1.998 & 1.160 & 1.419 & 1.371 \\
Skewness & -0.425 & -0.269 & -0.395 & -0.543 & -0.193 & -0.542 & -0.693 & -0.281 & -0.263 \\
Min & -0.283 & -0.058 & -0.177 & -0.274 & -0.219 & -0.190 & -0.136 & -0.254 & -0.228 \\
Max & 0.239 & 0.042 & 0.133 & 0.249 & 0.190 & 0.151 & 0.099 & 0.278 & 0.254 \\
\hline
\end{tabular}

Note. $\mathrm{R}_{\mathrm{m}}-\mathrm{R}_{\mathrm{f}}$ and $\mathrm{HML}$ denote market premium and low $\mathrm{C} / \mathrm{P}$ minus high $\mathrm{C} / \mathrm{P}$ premium.

Statistical properties that include mean, median, std. deviation are shown in the table. The mean value and standard deviation of value premium are 0.001 and $0.048,0.003$ and $0.046,0.004$ and 0.041 in Pakistan, India, and China respectively. The mean value and standard deviation of size premium are $-0.005 \& 0.027,-0.003 \&$ 0.046 and $-0.003 \& 0.073$ while market premium has mean value and standard deviation $0.003 \& 0.080,0.0090$ $\& 0.0700$ and $0.0040 \& 0.0410$ in Pakistan, India and China. The results indicate that average size premium is negative whereas average market premium and value premium are positive. Positive $H M L$ indicates that value stocks outperform the growth stocks. Negative $S M B$ shows that average of small stocks is lower than big stocks. $H M L, M K T$ and $S M B$ have maximum values $0.133,0.1510,0.25400 .239,0.2490,0.0990$ and 0.0420 .1900 , 0.2780 respectively. This shows the demand for maximum value, market, and size premium to take the risk. Whereas $H M L, M K T$ and $S M B$ have minimum values $-0.177,-0.1900,-0.2280,-0.283,-0.2740,-0.1360$ and $-0.058,-0.2190,-0.2540$ respectively. The standard value of Kurtosis is 3 . In this study, variables are normally distributed because the value of kurtosis is nearest to 3 .

Table 4. Comparative statement of Adj. $\mathrm{R}^{2}$

\begin{tabular}{ccccccc}
\hline & \multicolumn{2}{c}{ Pakistan } & \multicolumn{2}{c}{ India } & \multicolumn{2}{c}{ China } \\
\hline Variable & CAPM & 3FM-FF & CAPM & 3FM-FF & CAPM & 3FM-FF \\
\hline P & 0.438 & 0.720 & 0.385 & 0.527 & 0.619 & 0.764 \\
S & 0.450 & 0.637 & 0.301 & 0.465 & 0.474 & 0.666 \\
B & 0.243 & 0.711 & 0.319 & 0.706 & 0.344 & 0.494 \\
S/H & 0.234 & 0.472 & 0.231 & 0.529 & 0.395 & 0.636 \\
S/L & 0.234 & 0.541 & 0.585 & 0.633 & 0.424 & 0.680 \\
B/H & 0.148 & 0.442 & 0.377 & 0.657 & 0.375 & 0.495 \\
B/L & 0.300 & 0.560 & 0.447 & 0.683 & 0.378 & 0.676 \\
\hline
\end{tabular}


Adj. $\mathrm{R}^{2}$ indicates that explanatory power of model in explaining the returns of constructed portfolios. Results in Table 4 shows that portfolio returns are found significantly positive and are explained by CAPM. Whereas FF3F model has high explanatory power than for all sorted portfolios which show that FF3F can explain returns of portfolios in Pakistan, India and China stock market. Results indicate that FF three factors better explain return on stock then its explanatory power is higher than CAPM. Therefore it can be said that proposed model is better than CAPM.

Table 5. Two pass regression

\begin{tabular}{|c|c|c|c|c|c|c|c|}
\hline Variables & Intercept & 及1MKT & B2SMB & B3HML & Adj. $\mathbf{R}^{2}$ & F-Stat. & F. Sig \\
\hline \multicolumn{8}{|c|}{ Panel A-Regression for Pakistan } \\
\hline$\alpha$ & 0.011 & -0.007 & & & & & \\
\hline T-Value & 1.794 & -0.895 & & & -0.034 & 0.802 & 0.412 \\
\hline$P$ value & 0.133 & 0.412 & & & & & \\
\hline$\beta$ & -0.001 & 0.015 & -0.009 & 0.021 & & & \\
\hline T-Value & -0.060 & 0.497 & -0.249 & 0.644 & -0.454 & 0.376 & 0.779 \\
\hline P-value & 0.956 & 0.653 & 0.819 & 0.565 & & & \\
\hline \multicolumn{8}{|c|}{ Panel B-Regression for India } \\
\hline$\alpha$ & 0.005 & 0.008 & & & & & \\
\hline T Value & 0.195 & 0.249 & & & -0.185 & 0.062 & 0.813 \\
\hline P value & 0.853 & 0.813 & & & & & \\
\hline$\beta$ & -0.048 & 0.057 & 0.016 & 0.032 & & & \\
\hline T Value & -2.364 & 2.667 & 1.703 & 3.093 & 0.648 & 4.675 & 0.119 \\
\hline P value & 0.099 & 0.076 & 0.187 & 0.054 & & & \\
\hline \multicolumn{8}{|c|}{ Panel C-Regression for China } \\
\hline$\alpha$ & 0.020 & -0.012 & & & & & \\
\hline T Value & 0.808 & -0.414 & & & -0.160 & 0.171 & 0.696 \\
\hline P value & 0.456 & 0.696 & & & & & \\
\hline$\beta$ & 0.017 & -0.014 & 0.005 & -0.005 & & & \\
\hline T Value & 0.391 & -0.375 & 0.150 & -0.260 & -0.868 & 0.071 & 0.972 \\
\hline P value & 0.722 & 0.732 & 0.890 & 0.812 & & & \\
\hline
\end{tabular}

From historical data, future returns can be predicted through two pass regression analysis. Betas have been calculated on the basis of market, size and value premium. Calculated value and size premium does not have a significant relationship with portfolio returns in case of Pakistan. It simply shows that betas explain today's return and do not predict the future returns. The value of adjusted $\mathrm{R}^{2}$ is also very low that indicates independent variables are not able to explain significant variation in returns. Results show that there is no significant relationship between beta and portfolios return. There is no significant relationship between size and value premium with portfolio returns. This shows that these do not predict the future returns. The value of Adjusted $\mathrm{R}^{2}$ is low which indicates that independent variables do not predict any significant changes in stock returns. Results show that there is no significant relationship between beta and portfolios return. There is no significant relationship between size and value premium with portfolio returns. It just explains the today's returns but does not predict future return. The value of Adj. $\mathrm{R}^{2}$ is low which indicates that independent variables do not predict any significant changes in stock returns.

\section{Conclusion}

This study examines the impact of size and value premium across three emerging countries i.e. Pakistan, India, and China to check effects of Fama and French three-factor model (1993). Value premium is found positive for all created portfolios. Therefore it can be concluded that value effect is present in three emerging markets. High $C / P$ ratio outperforms the low $C / P$ ratio stocks. In this study $C / P$ ratio (value premium) integrated with size and market premium to check whether it can predict stock returns of small and large firms for high or low $C / P$ ratio. The finding is similar to (Lakonishok, Shleifer and Vishny (1994) and Hassan \& Javed (2011) that found the positive relationship of value premium and stock return and the negative relationship of size premium and stock return. The main focus of the study is to check the effect of $C / P$ ratio on stock returns in three emerging markets that includes Pakistan, China, and India by using the data of stock prices for the period of 2000 to 2015. This study includes a non-financial sector of emerging countries that includes listed companies (Pakistan, India, and China) and data is collected then portfolios are made. On the basis of market capitalization portfolios are sorted then on the basis of $C / P$ ratio portfolios are further sorted for the period of 2000 to 2015 . By applying descriptive 
statistics and to check the effect of the $C / P$ ratio on stock returns regression analysis has been used. This study also compares the results of CAPM with the help of table comparative statement. The findings of this study indicate that in Pakistan equity market, India equity market and China equity market, $C / P$ ratio based three-factor models significantly explains portfolio returns.

In the case of Pakistan descriptive power ranges from $33 \%$ to $91 \%$ for different portfolios with FF three-factor models. The explanatory power of FF three factors is higher explanatory power than CAPM that is $11 \%$ to $65 \%$. In the case of Indian equity market based on three-factor reveal FF3F model explain portfolios return and it has $43 \%$ to $87 \%$ explanatory power which is higher than CAPM. In Chinese equity market, C/P ratio based on three-factor shows fundamentally explain portfolio return and $44 \%$ to $82 \%$ is the explanatory power for different portfolios. So it is higher than explanatory power of CAPM. Fama \& French based on three factors that include market, size and value premium and this model better clarify stock returns in three emerging markets.

For constructing advance improvements in the study the attractive steps could be; to check the effect of value premium on stock returns of all sector of Pakistan, India, and China which includes financial and non-financial sector. Further variables of this domain and macroeconomic factors should be taken with stock returns. By using the attractive proxies such as WOV (weighted order value) that can explain returns variation in these countries. As this study predict the significance and positive relationship between value premium(C/P Ratio) and stock return in Asian emerging markets under study (Pakistan, China, India). This study can provide investors some assistance with judging the actual position of an organization and then deciding how investors should position their portfolios. Therefore, investors should carefully consider in their investment, financing and valuation decision. Investors should invest in those firms that have high $\mathrm{C} / \mathrm{P}$ ratio because firms with high cash to price ratio earn high returns. So this study is a valuable source of information for all investor who invests their funds.

\section{References}

Ball, R. (1978). Anomalies in relationships between securities' yields and yield-surrogates. Journal of Financial Economics, 6(2-3), 103-126. https://doi.org/10.1016/0304-405X(78)90026-0

Banz, R. W. (1981). The relationship between return and market value of common stocks. Journal of Financial Economics, 9(1), 3-18. https://doi.org/10.1016/0304-405X(81)90018-0

Basu, S. (1977). Investment performance of common stocks in relation to their price-earnings ratios: A test of the efficient market hypothesis. The journal of Finance, 32(3), 663-682. https://doi.org/10.1111/j.1540-6261.1977.tb01979.x

Black, F., Jensen, M. C., Scholes, M., \& Jensen, M. C. (1974). Studies in the theory of capital markets. The Journal of Finance, 29(5), 1604-1607. https://doi.org/10.2307/2978577

Blanco, B. (2012). The use of CAPM and Fama and French Three Factor Model: Portfolios selection. Public and Municipal Finance, 1(2), 62-63.

Chan, L. K., Hamao, Y., \& Lakonishok, J. (1991). Fundamentals and stock returns in Japan. The Journal of Finance, 46(5), 1739-1764. https://doi.org/10.1111/j.1540-6261.1991.tb04642.x

Choi, J. (2013). What drives the value premium? : The role of asset risk and leverage. The Review of Financial Studies, 26(11), 2845-2875. https://doi.org/10.1093/rfs/hht040

Diamond, P. (2006). Reforming Public Pensions in the US and the UK. The Economic Journal, 116(509). https://doi.org/10.1111/j.1468-0297.2006.01066.x

Djajadikerta, H., \& Nartea, G. (2005). The Size and Book-to-Market Effects and the Fama-French Three-Factor Model in Small Markets: Preliminary Findings from New Zealand (No. 2005-10).

Douglas, G. W. (1968). Risk in the equity markets: An empirical appraisal of market efficiency.

Drew, M. E., Naughton, T., \& Veeraraghavan, M. (2003). Firm size, book-to-market equity and security returns: Evidence from the Shanghai Stock Exchange. Australian Journal of Management, 28(2), 119-139.

Fama, E. F., \& French, K. R. (1988). Dividend yields and expected stock returns. Journal of Financial Economics, 22(1), 3-25. https://doi.org/10.1016/0304-405X(88)90020-7

Fama, E. F., \& French, K. R. (1992). The cross-section of expected stock returns. The Journal of Finance, 47(2), 427-465. https://doi.org/10.1111/j.1540-6261.1992.tb04398.x

Fama, E. F., \& French, K. R. (1993). Common risk factors in the returns on stocks and bonds. Journal of Financial Economics, 33(1), 3-56. https://doi.org/10.1016/0304-405X(93)90023-5 
Fama, E. F., \& French, K. R. (2017). International tests of a five-factor asset pricing model. Journal of Financial Economics, 123(3), 441-463. https://doi.org/10.1016/j.jfineco.2016.11.004

Fama, E. F., \& Kenneth, R. F. (2014). A five-factor asset pricing model. Journal of Financial Economics, 116(1), 1-22. https://doi.org/10.1016/j.jfineco.2014.10.010

Fama, E. F., \& MacBeth, J. D. (1973). Risk, return, and equilibrium: Empirical tests. Journal of Political Economy, 81(3), 607-636. https://doi.org/10.1086/260061

Hassan, A., \& Javed, M. T. (2011). Size and value premium in Pakistani equity market. African Journal of Business Management, 5(16), 6747. https://doi.org/10.5897/AJBM10.817

Jensen, M. C. (1969). Risk, the pricing of capital assets, and the evaluation of investment portfolios. The Journal of Business, 42(2), 167-247. https://doi.org/10.1086/295182

Jensen, M. C., Black, F., \& Scholes, M. S. (1972). The capital asset pricing model: Some empirical tests.

Lam, K. S. (2002). The relationship between size, book-to-market equity ratio, earnings-price ratio, and return for the Hong Kong stock market. Global Finance Journal, 13(2), 163-179. https://doi.org/10.1016/S1044-0283(02)00049-2

Mossin, J. (1966). Equilibrium in a capital asset market. Econometrica: Journal of the Econometric Society, 768-783. https://doi.org/10.2307/1910098

Pástor, L., \& Stambaugh, R. F. (2001). The equity premium and structural breaks. The Journal of Finance, 56(4), 1207-1239. https://doi.org/10.1111/0022-1082.00365

Pincus, M., Rajgopal, S., \& Venkatachalam, M. (2007). The accrual anomaly: International evidence. The Accounting Review, 82(1), 169-203. https://doi.org/10.2308/accr.2007.82.1.169

Reinganum, M. R. (1981). Misspecification of capital asset pricing: Empirical anomalies based on earnings' yields and market values. Journal of financial Economics, 9(1), 19-46. https://doi.org/10.1016/0304-405X(81)90019-2

Roll, R. (1977). A critique of the asset pricing theory's tests Part I: On past and potential testability of the theory. Journal of Financial Economics, 4(2), 129-176. https://doi.org/10.1016/0304-405X(77)90009-5

Rosenberg, B., Reid, K., \& Lanstein, R. (1985). Persuasive evidence of market inefficiency. The Journal of Portfolio Management, 11(3), 9-16. https://doi.org/10.3905/jpm.1985.409007

Rutledge, R. W., Zhang, Z., \& Karim, K. (2008). Is there a size effect in the pricing of stocks in the Chinese stock markets? The case of bull versus bear markets. Asia-Pacific Financial Markets, 15(2), 117-133. https://doi.org/10.1007/s10690-008-9074-0

Schwert, G. W. (1989). A Theory of Market Equilibrium under Conditions of Risk. Journal of Finance, 19, 425-442.

Schwert, G. W. (2003). Anomalies and market efficiency. Handbook of the Economics of Finance, Edited by Constantinides, Harris, and Stulz. https://doi.org/10.1016/S1574-0102(03)01024-0

Sloan, R. G. (2005). Do Stock Prices Fully Reflect Information in Accruals and Cash Flows about Future Earnings? Accounting Review, 71(3), 289-315.

\section{Copyrights}

Copyright for this article is retained by the author(s), with first publication rights granted to the journal.

This is an open-access article distributed under the terms and conditions of the Creative Commons Attribution license (http://creativecommons.org/licenses/by/4.0/). 